\title{
Tree species community spatial structure in a terra firme Amazon forest, Brazil
}

\author{
Estructura espacial de la comunidad de especies arbóreas en el "terra firme", \\ selva amazónica, Brasil
}

\author{
Kátia Emidio da Silva a*, Sebastião Venâncio Martins b ${ }^{\text {, }}$ Marie-Josée Fortin c, Milton Cezar Ribeiro d, \\ Celso Paulo de Azevedo ${ }^{a}$, Carlos Antonio Álvares Soares Ribeiro ${ }^{\text {b }}$, Nerilson Terra Santos ${ }^{\mathrm{e}}$ \\ *Corresponding author: a EMBRAPA, Brazilian Agricultural Research Corporation, Embrapa Western Amazonia, Manaus, \\ 69010-970, Amazonas, Brazil, katia.emidio@embrapa.br, celso.azevedo@embrapa.br \\ b Universidade Federal de Viçosa, Departamento de Engenharia Florestal, Viçosa, 36570-900, \\ Minas Gerais, Brazil, venancio@ufv.br, cribeiro@ufv.br \\ c University of Toronto, Department of Ecology and Evolutionary Biology, 25 Harbord St., \\ Toronto, Ontario, M5S 3G5, Canada, mariejosee.fortin@utoronto.ca \\ d Universidade Estadual Paulista-UNESP, Departamento de Ecologia, Rio Claro, Avenida 24 A, 1515, \\ Bela Vista, São Paulo, Brazil. mcr@rc.unesp.br \\ e Universidade Federal de Viçosa, Departamento de Estatística, Viçosa, 36570-000, Minas Gerais, Brazil, nsantos@ufv.br
}

\section{SUMMARY}

All trees with diameter at breast height $\mathrm{dbh} \geq 10.0 \mathrm{~cm}$ were stem-mapped in a "terra firme" tropical rainforest in the Brazilian Amazon, at the EMBRAPA Experimental Site, Manaus, Brazil. Specifically, the relationships of tree species with soil properties were determined by using canonical correspondence analyses based on nine soil variables and 68 tree species. From the canonical correspondence analyses, the species were grouped into two groups: one where species occur mainly in sandy sites, presenting low organic matter content; and another one where species occur mainly in dry and clayey sites. Hence, we used Ripley`s $K$ function to analyze the distribution of species in 32 plots ranging from 2,500 $\mathrm{m}^{2}$ to 20,000 $\mathrm{m}^{2}$ to determine whether each group presents some spatial aggregation as a soil variations result. Significant spatial aggregation for the two groups was found only at over $10,000 \mathrm{~m}^{2}$ sampling units, particularly for those species found in clayey soils and drier environments, where the sampling units investigated seemed to meet the species requirements. Soil variables, mediated by topographic positions had influenced species spatial aggregation, mainly in an intermediate to large distances varied range $(\geq 20 \mathrm{~m})$. Based on our findings, we conclude that environmental heterogeneity and 10,000 $\mathrm{m}^{2}$ minimum sample unit sizes should be considered in forest dynamic studies in order to understand the spatial processes structuring the "terra firme" tropical rainforest in Brazilian Amazon.

Key words: canonical correspondence analysis, Ripley`s K, spatial point pattern, Amazon forest, soil nutrients.

\section{RESUMEN}

Fueron mapeados los árboles con diámetro a la altura del pecho $\geq 10,0 \mathrm{~cm}$ en un bosque tropical lluvioso "terra firme" de la amazonía brasileña, en el Sitio Experimental de EMBRAPA, Manaus, Brasil. Las relaciones de 68 especies arbóreas con las propiedades del suelo fueron determinadas mediante análisis de correspondencia canónica sobre la base de nueve variables del suelo. En este análisis, las especies fueron agrupadas en dos grupos: uno, donde estas crecen principalmente en arena, con suelos de bajo contenido de materia orgánica, y otro, con especies que se desarrollan principalmente en suelos secos y arcillosos. La función $K$ de Ripley fue utilizada para analizar la distribución de las especies en 32 parcelas de 2.500 hasta $20.000 \mathrm{~m}^{2}$, con el fin de determinar si cada grupo presenta cierto grado de agregación espacial como resultado de variaciones del suelo. Una agregación espacial significativa para los dos grupos solo se encontró en unidades de muestreo $>10.000 \mathrm{~m}^{2}$, en particular, para especies en suelos arcillosos y ambientes más secos, en los que las unidades de muestreo parecían cumplir con los requisitos de las especies. Variables del suelo, mediadas por la posición topográfica, influyeron la agregación espacial de especies, principalmente en la gama de distancias intermedia a grande ( $\geq 20 \mathrm{~m}$ ). Según los resultados, se concluye que la heterogeneidad ambiental y tamaños de unidades de muestreo de por lo menos $10.000 \mathrm{~m}^{2}$ se deben considerar en los estudios de dinámica de bosques con el fin de entender los procesos espaciales que estructuran la selva tropical "terra firme” en la amazonía brasileña.

Palabras clave: análisis de correspondencia canónica, K Ripley’s, patrón punto espacial, los bosques del Amazonas, nutrientes del suelo.

\section{INTRODUCTION}

Identification of spatial structure is a key step in understanding the ecological processes structuring the distribution of plants in nature. Quantifying and relating the underlying generative processes that create these structures provide crucial information to help us interpret the factors which structure and maintain ecological diversity (Rossi 1994, 
Illian et al. 2008). The interactions between living communities and their environment, and among the organisms themselves, occur at definite spatial and temporal scales, and give rise to spatial patterns that must be assessed in order to better understand the processes structuring these communities (Bocard et al. 2004, Jombart et al. 2009, Amaral et al. 2013), which can also contribute to the selection of minimum-sized areas for management purposes.

In tropical Amazon forests, large numbers of species coexist, with high species diversity and low density of individuals per species (Condit et al. 2000). Indeed, several studies have recorded 200-300 tree species co-occurring in a single hectare; including only over $10 \mathrm{~cm}$ dbh trees (Amaral 1996, Ferreira and Prance 1998, Matos and Amaral 1999, Lima-Filho et al. 2001, Oliveira and Amaral 2005). Rainforest plant species have been found to be associated with particular edaphic, topographic or successional conditions due to their strong effects on niche or microsite diversity in landscapes which are topographically heterogeneous (Tuomisto and Ruokolainen 1994, Clark et al. 1998, Valencia et al. 2004, Tuomisto 2006, Jones et al. 2007, Hofer et al. 2008, Quesada et al. 2009).

Forest structure and dynamics vary across the Amazon basin in an east-western gradient following a pattern coinciding with soil fertility, physical properties and geomorphological variation, showing that edaphic properties play an important role in accounting for forest biomass, species composition and diversity (Hofer et al. 2008, Quesada et al. 2009). While generalist species occur in all types of soils, other species have strong relationships to soil variables. Then, finding out how species are organized in space according to environmental heterogeneity (spatial dependence) may reveal patterns that can help understand the biological processes generating such structures (Legendre and Legendre 1998, Illian et al. 2008, Law et al. 2009).

Spatial structure quantification, however, is directly related to and bounded by the study area (extent) and the sampling unit size (grain) (Wiens 1989, Fortin and Dale 2005, Massant et al. 2009). The present study was conducted in a "terra firme" tropical rain Forest near Manaus, Amazonas State Brazil and aimed at investigating in what plot size the spatial relationship among soil variables influence species spatial distribution in tree communities.

\section{METHODS}

Study area. The study area is located in a Western Brazilian Amazon "terra firme" dense forest, at EMBRAPA Experimental site (Manaus, Amazonas state, Brazil); coordinates 59 $59^{\prime} 42.6^{\prime \prime} \mathrm{W}$ and $2^{\circ} 32^{\prime} 49.7^{\prime \prime} \mathrm{S}$. The climate is tropical, "Am" type (Koppen classification), averaging 2,137 mm rainfall annually. The mean annual temperature is $26{ }^{\circ} \mathrm{C}$, with $85 \%$ relative humidity (Brazil 1978). On a broad scale, soils are fairly homogeneous throughout the stands, with the predominance of heavy-textured dystrophic yellow latosol, covered mainly by dense forest with emergent trees (IBGE 1999), but with a degree of local variation in topographic and edaphic conditions (Silva 2010).

Field sampling. Since topography may influence soil fertility, generating gradients (Hofer et al. 2008, Quesada et al. 2009) we used a randomly stratified sampling of fifteen $2,500 \mathrm{~m}^{2}$ plots aiming at collecting soil samples, which were evenly distributed in each topographic category (top, slope and base). These 15 plots were used to relate soil variables to species composition through canonical correspondence analyses (CCA). Next, 32 random plots located at different topographic positions, distributed in five sampling unit sizes throughout the study area were used, in order to identify in which sampling unit size the spatial dependence between soil variables and species community could be detected: (1) fifteen, each measuring 2,500 $\mathrm{m}^{2}$, likewise the ones used in CCA; (2) six presenting irregular shapes, ranging from 4,270 to $5,870 \mathrm{~m}^{2}$; (3) nine of 10,000 $\mathrm{m}^{2}$ each (100 x $\left.100 \mathrm{~m}\right)$; (4) one measuring 14,300 $\mathrm{m}^{2}$; and (5) one with $20,000 \mathrm{~m}^{2}$ (100 x $\left.200 \mathrm{~m}\right)$.

In 2005, in the five sampling unit sizes, all $\mathrm{dbh} \geq 10 \mathrm{~cm}$ trees were mapped ( $x-y$ coordinates) and identified to species level. Since the study area covers two Universal Transverse Mercator (UTM) zones, all trees were georeferenced to the Local Transverse Mercator (zone 21 and central meridian $60 \mathrm{~W}$ ), placing the data into a single zone.

Canonical correspondence analyses (CCA). A canonical correspondence analysis was performed for identifying tree species/soil properties relationship (Jongman et al. 1995, Legendre and Legendre 1998), by using soil variables sampled down to $20 \mathrm{~cm}$ deep at fifteen $2,500 \mathrm{~m}^{2}$ plots. Each sample was a composite of three, at least $10 \mathrm{~m}$ apart, subsamples. Chemical (macro/micronutrients) and physical (texture) analyses were carried out for each soil sample according to (EMBRAPA 1997); afterwards, nine soil variables were used at CCA: soil $\mathrm{pH}$, organic matter (MO), phosphorus, iron, zinc and manganese concentration, aluminum toxicity (\%m), sum of bases-SB (calcium, magnesium, potassium, sodium) and sand percentage (S).

We worked with species recorded at a minimum frequency of $60 \%$ (i.e. present in at least nine of the 15 sampled plots), having more than five individuals and removing the most frequent species (present in almost everywhere), remaining 68 species to CCA analyses, in order to identify some "species preferences" along the gradient of soil variables. Our intent was to include species that could show some degree of dispersal along the soil variables gradient (selectivity). PAST software was used to perform CCA (Hammer and Harper 2009).

Since our aim was to study the spatial structure of species assemblage (hereafter called community), we separated the 68 species into two groups by using their scores, in the two axes of CCA, superior or equal to $|0.5|$, avoiding species too close to the origin axes. Finally, we performed the point pattern analysis considering these two species 
groups analyzed at the five sampling unit sizes, comprising the 32 plots described above.

Point pattern analyses. Spatial point processes are stochastic models that serve as appropriate tools for the analysis of patterns in ecological communities, representing the locations of objects in two- or more-dimensional spaces (Wiegand and Moloney 2004, Illian and Burslem 2007). We used the univariate Ripley`s $K$ analysis, applied to the two species groups selected from CCA, to investigate the spatial structure of the community in the study area according to environmental factors (soil variables), (Shimatani and Kubota 2004, Wiegand and Moloney 2004, Fortin and Dale 2005, Illian et al. 2008). The study was conducted across the five sampling unit sizes, and the results were plotted as " $L(r)-r$ " instead of $K$, which is a transformation of the Poisson $K$ function to the straight line, with a constant value $=0$, making it easier to assess the deviation from the theoretical function.

Monte Carlo tests were carried out, with a $5 \%$ probability level, to test the empirical functions against the theoretical one, constructing simultaneous envelopes for the critical values under the null hypothesis of complete spatial randomness (CSR). The test rejects the null hypothesis if the graph of the observed function lies outside the linearized envelope at any " $r$ " distance value (Baddeley 2008). The spatial analysis was performed by using the Spatstat package in R (R-DCT 2011).

\section{RESULTS}

Canonical correspondence analyses (CCA). Based on the species scores $\geq|0.5|$ shown on CCA over the fifteen 2,500 $\mathrm{m}^{2}$ plots, we separated the species into two groups along the first two axes, which accounted for $52 \%$ of the composition variation (figure 1 and table 1). Group 1 related 21 species to areas having sandy soils, higher phosphorus concentration, lower iron concentration, less organic matter, less acidity and, in general, located at the lowest topographic position (base). Group 2 related 31 species to areas with higher clay and organic-matter (OM) content. According to what is known about this area, in general, the more humid and sandy plots are in the lowest topographic position, along stream valleys, whereas the drier clayey plots are on plateaus (top position).

The first CCA axis in figure 1 showed that the species composition is mainly correlated with manganese, organic matter and zinc concentration and sandy soils. The second one indicated species correlated with phosphorus and iron concentrations and aluminum toxicity (\% m).

In our study area, based on the fifteen $2,500 \mathrm{~m}^{2}$ plots, the ones with higher clay and organic matter contents, associated with group 2 species, are those having on average larger individual number (n) and basal area (BA) $(n=150$ and $\mathrm{BA}=7.021 \mathrm{~m}^{2}$, respectively), as compared with those presenting higher sand and phosphorus content $(n=103$ and $\mathrm{BA}=4.33)$, which are associated with group 1 species.

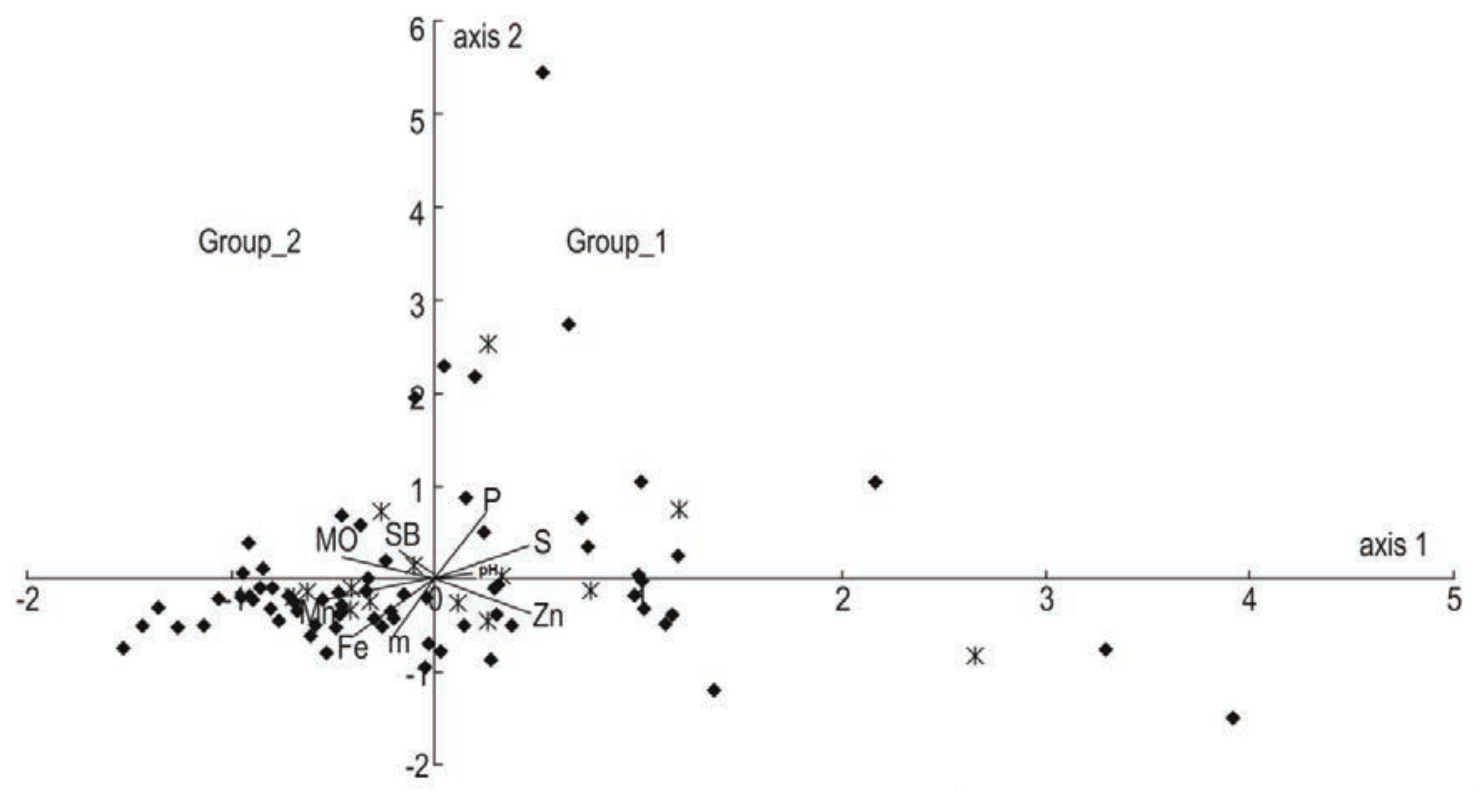

* Plots • Species — Soil Variables

Figure 1. CCA triplot based on 68 species, 15 plots and nine soil variables, for "terra firme" tropical rain forest data, at the EMBRAPA Experimental Site, Manaus, Amazonas, Brazil.

CCA triespacial basado en 68 especies, 15 parcelas y nueve variables del suelo, para datos de la selva tropical de "terra firme", en el Sitio Experimental EMBRAPA, Manaus, Amazonas, Brasil. 
Table 1. Species list resulting from CCA, grouped into two groups and used for Ripley's K analyses at the EMBRAPA experimental site, Manaus, Amazonas, Brazil.

Listado de especies resultantes del CCA, agrupadas en dos conjuntos y utilizados para el análisis K de Ripley en el sitio experimental de EMBRAPA, Manaus, Amazonas, Brasil.

\begin{tabular}{|c|c|c|}
\hline Group & Scientific name & Family \\
\hline g1 & Abarema jupunba (Willd.) Britton et Killip & Fabaceae-Mimosoideae \\
\hline g1 & Aparisthmium cordatum (A.Juss.) Baill. & Euphorbiaceae \\
\hline g1 & Carapa guianensis Aubl. & Meliaceae \\
\hline g1 & Chrysophyllum sanguinolentum (Pierre) Baehni & Sapotaceae \\
\hline g1 & Endopleura uchi (Huber) Cuatrec. & Humiriaceae \\
\hline g1 & Eperua duckeana R.S. Cowan & Fabaceae- Caesalpinioideae \\
\hline g1 & Erythroxylum amplum Benth. & Erythroxylaceae \\
\hline g1 & Eschweilera truncata A.C. Sm. & Lecythidaceae \\
\hline g1 & Eschweilera wachenheimii (Benoist) Sandwith & Lecythidaceae \\
\hline g1 & Guatteria olivacea R.E. Fr. & Annonaceae \\
\hline g1 & Inga alba (Sw) Willd. & Fabaceae-Mimosoideae \\
\hline g1 & Inga suberosa T.D. Penn. & Fabaceae-Mimosoideae \\
\hline g1 & Macrolobium limbatum Spruce ex Benth. & Fabaceae- Caesalpinioideae \\
\hline g1 & Protium heptaphyllum (Aubl.) ssp. ulei (Swart) Daly & Burseraceae \\
\hline g1 & Protium pilosissimum Engl. & Burseraceae \\
\hline g1 & Simarouba amara Aubl. & Simaroubaceae \\
\hline g1 & Sterculia pruriens (Aubl.) K. Schum. & Malvaceae \\
\hline g1 & Tapura amazonica Poepp. ex Endl. & Dichapetalaceae \\
\hline g1 & Theobroma subincanum Mart. & Malvaceae \\
\hline g1 & Theobroma sylvestre Aubl. ex. Mart. & Malvaceae \\
\hline g1 & Trattinnickia burserifolia Mart. & Burseraceae \\
\hline g2 & Agonandra brasiliensis Miers ex. Benth. et Hook. f. & Opiliaceae \\
\hline g2 & Aspidosperma marcgravianum Woodson & Apocynaceae \\
\hline g2 & Couratari alta Kunth. & Lecythidaceae \\
\hline g2 & Dystomovita paniculata (Donn. Sm.) Hammel & Clusiaceae \\
\hline g2 & Eschweilera atropetiolata S.A. Mori & Lecythidaceae \\
\hline g2 & Geissospermum argenteum Woodson & Apocynaceae \\
\hline g2 & Goupia glabra Aubl. & Goupiaceae \\
\hline g2 & Helicostylis scabra (J.F. Macbr.) C.C. Berg & Moraceae \\
\hline g2 & Helianthostylis spruce Baill. & Moraceae \\
\hline g2 & Hevea guianensis Aubl. & Euphorbiaceae \\
\hline g2 & Lecythis gracieana S.A. Mori & Lecythidaceae \\
\hline g2 & Lecythis pisonis Cambess. & Lecythidaceae \\
\hline g2 & Licaria guianensis Aubl. & Lauraceae \\
\hline g2 & Licania sp. & Lauraceae \\
\hline g2 & Mabea sp. & Euphorbiaceae \\
\hline g2 & Manilkara bidentata (A. DC.) A. Chev. & Sapotaceae \\
\hline g2 & Micropholis trunciflora Ducke & Sapotaceae \\
\hline g2 & Mouriri callocarpa Ducke & Melastomataceae \\
\hline g2 & Neea oppositifolia Ruiz et Pav. & Nyctaginaceae \\
\hline g2 & Pithecellobium elegans Ducke & Fabaceae-Mimosoideae \\
\hline g2 & Pouteria caimito (Ruiz et Pav.) Radlk. & Sapotaceae \\
\hline g2 & Pouteria caimito var. laurifolia (Gomes) Baehni & Sapotaceae \\
\hline g2 & Pouteria venosa (Mart.) Baehni & Sapotaceae \\
\hline g2 & Ptychopetalum olacoides Benth. & Olacaceae \\
\hline g2 & Rinorea racemosa (Mart.) Kuntze & Violaceae \\
\hline g2 & Stryphnodendron sp. & Fabaceae-Mimosoideae \\
\hline g2 & Swartzia recurva Poepp. & Fabaceae-Faboideae \\
\hline g2 & Talisia cf. cupularis Radlk. & Sapindaceaea \\
\hline g2 & Trichilia micropetala T.D. Penn. & Meliaceae \\
\hline g2 & Unonopsis duckei R.E. Fr. & Annonaceae \\
\hline g2 & Xylopia calophylla R.E. Fr. & Annonaceae \\
\hline
\end{tabular}


Of the 53 families identified over all the 15 mapped 2,500 $\mathrm{m}^{2}$ plots, 31 were included in the two groups of species studied. Only six families: Annonaceae, Euphorbiaceae, Fabaceae-Mimosoideae, Lecythidaceae, Meliaceae, and Sapotaceae were common to both groups. The species in the sandy plots (group 1) are represented by 13 families, of which five: Burseraceae, Sapotaceae, Malvaceae, Fabaceae-Caesalpinioideae and Fabaceae-Mimosoideae comprised $69 \%$ of the total number of individuals in this group. Species occurring in more-acid soils with higher clay and organic mater contents (group 2) are represented by 18 families, with Sapotaceae, Lecythidaceae, Annonaceae, Moraceae, and Lauraceae comprising $55 \%$ of the total number of individuals.

Some species were well distinguished by the CCA axes in both groups, occurring in plots with different soil conditions. Within group 1, species such as Abarema jupunba (Willd.) Britton and Killip, Eperua duckeana R.S. Cowan, Erythroxylum amplum Bth., Macrolobium limbatum Spruce ex Benth and Carapa guianensis Aubl., were found mainly near plots with more sand and higher phosphorus (figure 3) and moisture content (Silva 2010, Silva et al. 2011). Within group 2, we observed that Xylopia calophylla R.E. Fr., Manilkara bidentata (A.DC.) A. Chev., Goupia glabra Aubl., Lecythis gracieana S.A. Mori and
Dystomovita brasiliensis D’Arcy, among others, occurred in clayey soils with higher OM content as compared with the species in group 1 .

Point pattern analyses. The point pattern analysis performed for the two groups individually showed that CCA was helpful to reveal structure in the species assemblage only when the sample unit size was large enough to allow the detection of spatial dependence. That is, in sample unit sizes varying from $2,500 \mathrm{~m}^{2}$ up to $5,870 \mathrm{~m}^{2}$, the univariate Ripley`s $K$ analyses detected no significant spatial pattern for the two groups. As the sample unit sizes increased, some degree of structure began to appear. This was observed for five out of nine $10,000 \mathrm{~m}^{2}$ plots where species showed some structure within both groups, which are presented in figure 2. Species occurring in more-acid, clayey and drier plots (group 2) showed aggregation over small to large scales, with some variation in the resulting patterns across plots (figure 2A, B, C). For species in the sandy and wetter plots (group 1), aggregation was observed for distances from $25 \mathrm{~m}$ up to $55 \mathrm{~m}$ (figure 2D, E).

The same tendency of showing spatial pattern was observed when the 14,000 $\mathrm{m}^{2}$ sample unit size was analyzed for group 2 species occurring in the drier, clayey and more acid plots, with a clearer pattern for larger than $22 \mathrm{~m}$ dis-
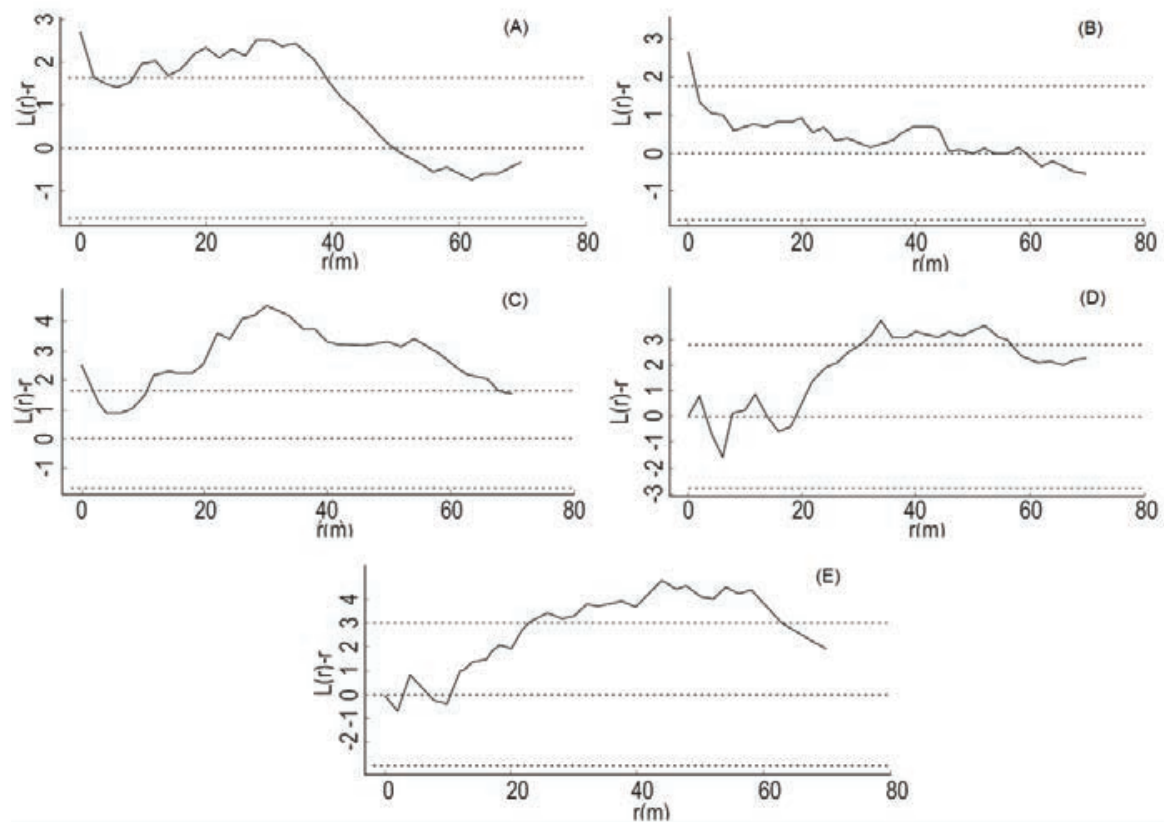

Figure 2. Ripley`s function " $L(r)-r$ ”, univariate analyses at $10,000 \mathrm{~m}^{2}$ plots at the EMBRAPA Experimental Site. From (A) to (C) are the plots where species of group 2 showed different patterns from Complete Spatial Randomness-CSR; (D) and (E), are the plots where species of group 1 showed significant patterns. Upper and lower dotted lines represent the critical envelope under the CSR null hypothesis. The dotted line at " $L(r)-r$ " $=0$ represents the Poisson $K$ function under CSR.

Función de Ripley G (r)-r “. Análisis univariado en parcelas de $10.000 \mathrm{~m}^{2}$ en el Sitio Experimental de EMBRAPA. De (A) a (C) son las parcelas donde las especies del grupo 2 mostraron diferentes patrones de aleatoriedad espacial completa con CSR, (D) y (E) son las parcelas donde las especies del grupo 1 mostraron patrones significativos. Líneas superior e inferior de puntos representan la envolvente crítico bajo la CSR hipótesis nula. La línea de puntos en "L (r) - r" = 0 representa la función de Poisson K bajo la CSR. 
tances (figure 3B). However, species in the sandy and wetter plots (group 1) revealed no different pattern from CSR for the univariate analyses (figure 3A).

The effect of the environmental factors (soil variables) structuring the distribution of species was better observed in the largest 20,000 $\mathrm{m}^{2}$ sample unit size. The analyses carried out including all species occurring in that plot,

(A)
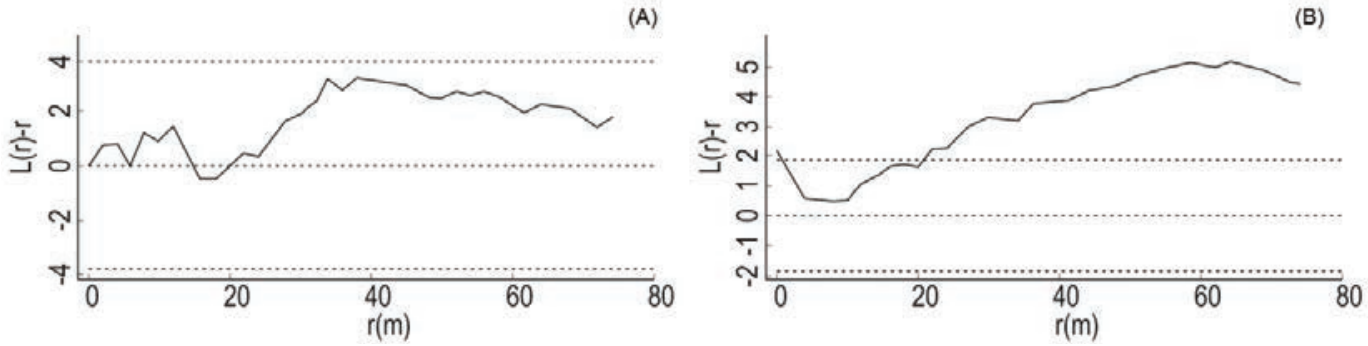

Figure 3. Ripley`s function “ $L(r)-r$ ”, univariate analyses at 14,000 $\mathrm{m}^{2}$ at the EMBRAPA Experimental Site. (A) Group 1 ; (B) group 2. Función de Ripley “ $L(r)-r$ ”, el análisis univariado a 14.000 m² en el Sitio Experimental EMBRAPA. (A) Grupo 1, (B) grupo 2.
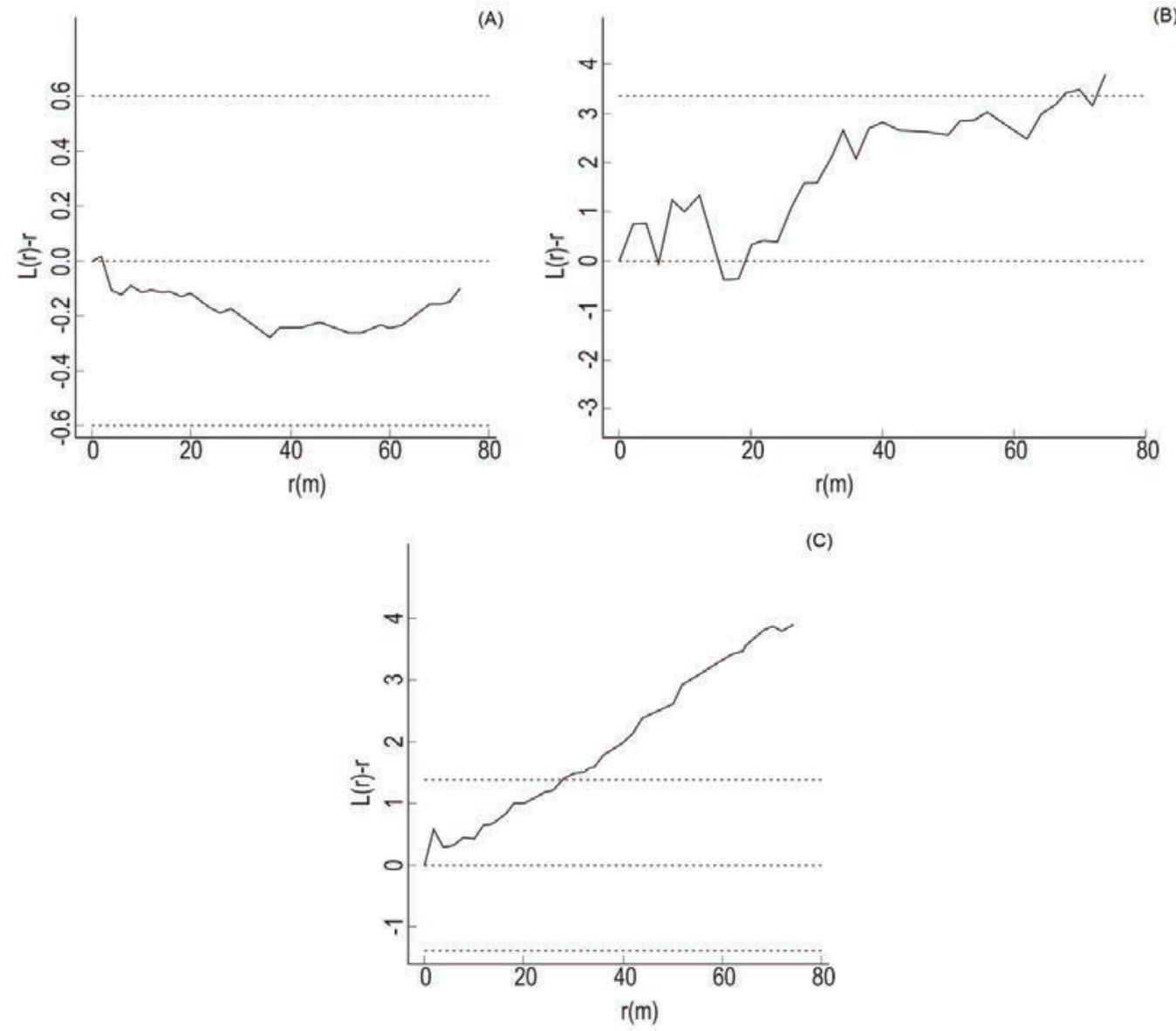

Figure 4. Ripley`s function " $L(r)-r$ ”, for the $20,000 \mathrm{~m}^{2}$ plot. (A) all species in the plot are considered, without being separated into groups; (B) species found in group 1 and (C) species in group 2.

Función de Ripley “ $L(r)$ - $r$ ” para la parcela de $20.000 \mathrm{~m}^{2}$. (A) Considera todas las especies en el gráfico, sin separar en grupos, (B) especies que se encuentran en el Grupo 1 y (C) las especies en el grupo 2. 


\section{DISCUSSION}

The direct gradient analysis-CCA identifies the compositional gradient in vegetation as a response to measured environmental factors, which are often spatially structured (Wagner 2003). The results found in our study have shown that environmental heterogeneity influences how tree species composition is organized in this forest, with a strong effect of spatial dependence among species and soil variables; initially identified at the intermediate sample unit size $\left(10,000 \mathrm{~m}^{2}\right)$ but best resolved at sizes $>14,000 \mathrm{~m}^{2}$ (figures 2, 3 and 4). Poulsen et al. (2006) found that differences in elevation and soil factors were highly correlated with floristic differences within a 1-ha plot in a tropical rainforest in Ecuador, indicating that soil factors may have played an important role for plants distribution and beta diversity, even at local scale. Also, Coronado et al. (2009) found soil fertility to be a good predictor for studies on floristic patterns in the Amazon Basin.

Many studies conducted in tropical rainforests have indicated that species respond differently to environmental factors, and soil variables are commonly studied because of their importance in accounting for variations in species distribution and performance (Tuomisto 2006, Baltzer et al. 2007, Jones et al. 2007). Despite the generally low fertility found throughout the study area (on average, base saturation of $0.18 \mathrm{cmol}_{\mathrm{c}} \mathrm{dm}^{-3}$ and effective cation exchan-

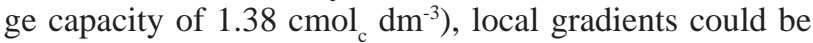
detected. Our plots ranged from plateaus to lowland areas in stream valleys (Silva 2010), which form a gradient in topography and soil conditions that varied in fertility and texture in west-eastern, as well as northwest-southwestern directions. Coronado et al. (2009) and Quesada et al. (2009) also highlighted soil fertility and soil physical properties variations across the Amazon basin in a west-eastern gradient, in a regional scale, which also affected the forest structure and dynamics in the same directions. Our study showed the same tendency in a local scale. Phillips et al. (2004) suggested that an edaphic resource gradient, mediated by soil quality, was likely the cause of the observed floristic gradient in their study of pattern and process in the Amazon tree turnover.

The separation of species into two groups based on CCA, revealed species to be occurring in plots presenting gradient in soil features, which resulted in differences in the spatial patterns for the studied groups. The observed differences between the two groups (from figure 2 and onwards) were mainly affected by texture, organic matter $(\mathrm{OM})$ and aluminum toxicity $(\mathrm{m})$ variations, which could be the result of the sampling units topographic position, contributing to soil features variations. Laurance et al. (1999) studied the relationship between soils and Amazon forest biomass in forests neighboring our study area, and found that areas with higher clay content were also associated with higher OM content and more-acid sites presenting low phosphorus and high aluminum saturation.
The aggregated pattern found for species in group 2, observed in over or equal to 1-ha sized plots, attracted our attention to the fact that the largest number of these plots are located in the top position, where drier and more-acid soils are to be expected (Silva 2010). This situation seemed to favor species in group 2, which were more frequently found in plots having these soil characteristics, showing the effect of sampling unit size structuring species distribution. In the 14,000 $\mathrm{m}^{2}$ sampling unit size strong aggregation was observed for species in group 2; again reinforcing the fact that species soil requirements seem to match this plot feature, which lies completely within the landscape top position (figure 3B). No similar pattern was observed for species in Group 1 (figure 3A), highlighting topographymediated soil variations effect (Hofer et al. 2008, Quesada et al. 2009). Further investigations including explicit spatial information on soil variables and plots located over the entire area's topographical variation, mainly in the base (low) position, can help to better characterize the species growing in moister sandy soils responses (group 1).

Sampling unit size influenced the perceived variations in species community spatial structure in our study. Cunha (2003) studied the spatial patterns of three $\geq 35 \mathrm{~cm} \mathrm{dbh}$ tropical tree species in Pará State, Brazil, for management purposes and concluded that 100 ha should be the minimum unit size studied. This conclusion was probably influenced by the minimum diameter used, which resulted in a small number of individuals above this diameter class. Because Amazon terra firme forests are typically composed by many low density species, relatively larger areas are required in order to attain a comprehensive view of compositional patterns. In the present study, a minimum 1-ha sampling unit size was necessary to obtain a better view of the spatial dependence of species distributions on soil variables. These results corroborated the permanent plots sizes currently used to study the dynamic and ecological aspects of natural tropical rainforests in Brazil (Silva et al. 2005). However, both plot minimum sizes and environmental heterogeneity must be considered for conservation and management purposes, once that knowledge can help defining management strategies for a group of species sharing similar behavior.

\section{CONCLUSIONS}

Our results contributed to the knowledge of the spatial structure of the Amazon tropical tree community, specifically for the "terra firme" tropical rainforests in Brazil. In the present study, the observed soil fertility and texture gradients repeat the same west-eastern tendency observed at broad and regional scales noted in several studies across the Amazon basin.

Our findings showed species to be organized along soil variables gradient, especially in plots that meet the species requirements, but only at a 1-ha minimum sample unit size. These results provide important information for the 
design of sampling units and ecological studies related to forest dynamics for both management purposes and conservation programs. Such studies must include the environmental heterogeneity based on an appropriate scale of analyses, in order to better understand, characterize and protect the "terra firme" tree species communities structure in the Amazon region.

\section{ACKNOWLEDGMENTS}

We are grateful to the Western Amazonia EMBRAPA, as well as the Amazon Forest Management Project (MFA), for providing the means for acquiring the data being presented in the study, and also the Federal University of Viçosa, Forestry Department, and the University of Toronto, particularly the Landscape Ecology Laboratory where analyses were performed, and Janet W. Reid and Jorge Antunes for helping to correct the English version of the original manuscript.

\section{REFERENCES}

Amaral IL. 1996. Diversidade florística em floresta de terra firme, na região do rio Urucu- AM. Thesis Magister in Botany. Manaus, Brasil. Instituto Nacional de Pesquisas da Amazônia, Universidade Federal do Amazonas. 160 p.

Amaral LP, RA Ferreira, LF Watzlawick, SJ Longhi, E Sebem. 2013. Influência da floresta alterada na distribuição espacial de três espécies da Floresta Ombrófila Mista avaliada pela geoestatística. Revista Árvore 37(3): 491-501.

Baddley A. 2008. Analyzing spatial point patterns in R. CSIRO and University of Western Australia. Workshop. Accessed 22 mar. 2009. Available in http://school.maths.uwa.edu. $\mathrm{au} / \sim$ adrian/.

Baltzer JL, SJ Davies, N Noor, AR Kassin, JV Lafrankie. 2007. Geographical distributions in tropical trees: can geographical range predict performance and habitat association in cooccurring tree species? Journal of Biogeography 34(11): 1916-1926.

Bocard D, PLegendre, C Avois-Jacquet, H Tuomisto. 2004. Dissecting the spatial structure of ecological data at multiple scales. Ecology 85: 1826-1832.

BRASIL (Departamento Nacional da Produção Mineral, BR). 1978. Folha SA.20-Manaus. 628 p. (Projeto Radam Brasil $\left.\mathrm{N}^{\circ} 18\right)$.

Clark DA, DA Clark, JM Read. 1998. Edaphic variation and the mesoscale distribution of tree species in a neotropical rain forest. Journal of Ecology 86(1): 101-112.

Condit R, PS Ashton, P Bakser, S Bunyavejchewin, S Gunatileke , N Gunatilleke, SP Hubbell, RB Foster, A Itoh, JV LaFrankie, HS Lee, E Losos, N Manokaran, R Sukumar, $\mathrm{T}$ Yamakura. 2000. Spatial patterns in the distribution of tropical tree species. Science 288(5470): 1414-1418.

Coronado ENH, TR Baker, OL Phillips, NCA Pitman, RT Pennington, RV Martinez, A Monteagudo, H Mogollon, ND Cardozo, M Rios, R Garcia-Villacorta, E Valderrama, M Ahuite, I Huamantupa, DA Neill, WF Laurance, HEM Nascimento, SS Almeida, TJ Killeen, L Arroyo, P Nunez, LF Alvarado. 2009. Multi-scale comparisons of tree composi- tion in Amazonian terra firme forests. Biogeography Discussion 6: 2719-2731.

Cunha US. 2003. Análise da estrutura espacial de uma floresta de terra firme da Amazônia. Thesis in Forestry Science. Curitiba, Brasil. Universidade Federal do Paraná. 126 p.

EMBRAPA (Empresa Brasileira de Pesquisa Agropecuária, Centro Nacional de Pesquisa de Solos- CNPS, BR). 1997. Manual de métodos de análise de solo. 212 p. (Documento $\mathrm{N}^{\circ} 1$ ).

Ferreira LV, GT Prance. 1998. Species richness and floristic composition in four hectares in the Jaú National Park in upland forests in Central Amazonia. Biodiversity and Conservation 7(10): 1349-1364.

Fortin MJ, MRT Dale. 2005. Spatial analysis: a guide for ecologists. Cambridge, England. Cambridge University Press. $365 \mathrm{p}$.

Hammer O, DAT Harper. 2009. PAST: Paleontological statistical package for education and data analysis. V. 1.92. Accessed 15 sep. 2009. Available: http://folk.uio.no/ohammer/past).

Hofer G, HH Wagner, F Herzog , PJ Edwards. 2008. Effects of topographic variability on the scaling of plant species richness in gradient dominated landscapes. Ecography 31(1): 131-139.

IBGE (Instituto Brasileiro de Geografia e Estatística, BR). 1999. Mapa digital temático de vegetação-Banco de dados Sipam. CD-ROM. Brazil.

Illian J, D Burslem. 2007. Contributions of spatial point process modeling to biodiversity theory. Journal de la Société Française de Statistique 148(1): 9-29.

Illian J, A Penttinen, H Stoyan, D Stoyan. 2008. Statistical analysis and modelling of spatial point patterns. Chichester, England. John Wiley \& Sons. 534p.

Jombart T, S Dray, A Dufour. 2009. Finding essential scales of spatial variation in ecological data: a multivariate approach. Ecography 32(1): 161-168.

Jones MM, H Tuomisto, DB Clark, P Olivas. 2007. Effects of mesoscale environmental heterogeneity and dispersal limitation on floristic variation in rain forest ferns. Journal of Ecology 94(1): 181-195.

Jones MM, RP Olivas, H Tuomisto, DB Clark. 2007. Environmental and neighbourhood effects on tree fern distributions in a neotropical lowland rain Forest. Journal of Vegetation Science 18(1): 13-24.

Jongman RHG, CJF Ter Braak, OFR Tongeren. 1995. Data analysis in community and landscape ecology. Wageningen, Netherlands. Cambridge University Press. 299 p.

Laurance WF, PM Fearnside, SG Laurance, P Delamônica, TE Lovejoy, JM Rankin-de-Merona, J Chambers, C Gascon. 1999. Relationship between soils and Amazon forest biomass: a landscape-scale study. Forest Ecology and Management 118(1-3): 127-138.

Law R, J Illian, DFRP Burslem, G Gratzer, CVS Gunatilleke, IAUN Gunatilleke. 2009. Ecological information from spatial patterns of plants: insights from point process theory. Journal of Ecology 97(4): 616-628.

Legendre P, L Legendre. 1998. Numerical ecology. Amsterdam, Holanda. Elsevier. 870 p.

Lima-Filho DA, FDA Matos, IL Amaral, J Revilla, LS Coelho, JF Ramos, JL Santos. 2001. Inventário florístico de floresta ombrófila densa de terra firme, na região do Rio UrucuAmazonas, Brasil. Acta Amazonica 31: 565-579.

Massant W, S Godefroid, N Koedam. 2009. Clustering of plant 
life strategies on meso-scale. Plant Ecology 205: 47-56.

Matos FDA, IL Amaral. 1999. Análise ecológica de um hectare em floresta ombrófila densa de terra-firme, estrada da várzea, Amazonas, Brasil. Acta Amazonica 29: 365-379.

Oliveira NA, IL Amaral. 2005. Aspectos florísticos, fitossociológicos e ecológicos de um sub-bosque de terra firme na Amazônia Central, Amazonas, Brasil. Acta Amazonica 35: 1-16.

Phillips OL, TRM Bajerm, L Arroyo, N Higuchi, TJ Killen, WF Laurance, SL Lewis, J Lloyd, Y Malhi, A Monteagudo, DA Neill, PN Vargas, JNM Silva, J Terborg, RV Martínez, M Aleixiades, S Almeida, S Brown, J Chave, JA Comiskey, CI Czimczik, AD Fiore, T Erwin, C Kuebler, SG Laurance, HEM Nascimento, J Olivier, W Palacios, S Patiño, NCA Pitman, CA Quesada, M Saldias, AT Lezama, B Vinceti. 2004. Pattern and process in Amazon tree turnover, 19762001. Philosophical Transactions of the Royal Society 359(1443): 381-407.

Poulsen, AD, H Tuomisto, H Balslev. 2006. Edaphic and floristic variation within a 1-ha plot of lowland Amazonian Rain Forest. Biotropica 38(4): 468-478.

Quesada CA, J Loyd, M Schwartz, TR Baker, OL Phillips, S Patino, CI Czimczik, MG Hodnett, R Herrera, A Arneth, G Lloyd, Y Malhi, N Dezzeo, FJ Luizao, AJB Santos, J Schmerler, L Arroyo, M Silveria, N Priante Filho, EM Jimenez, R Paiva, I Vieira, DA Neil, N Silva, A Monteagudo, R Vasquez, A Prieto, A Rudas, S Almeida, N Higuchi, AT Lezama, G Lopez-Gonzalez, J Peacock, NM Fyllas, E Alvarez Davila, T Erwin, A Di Fiore, KJ Chao, E Honorio, T Killen, A Pena Cruz, N Pitman, P Nunez Vargas, R Salomao, J Terborgh, H Ramirez. 2009. Regional and large-scale patterns in Amazon forest structure and function are mediated by variations in soil physical and chemical properties. Biogeography Discusssion 6(2): 3993-4057.

R Core Team. 2011. R: A language and environment for statistical computing (V.2.9.0). Spatstat Package. Vienna, Austria. Accessed 12 mar. 2011. Available in http://www.R-project.org.

Regis, WDE. 1993. Unidades de Relevo. In Caldeiron SS ed. Recursos naturais e meio ambiente: uma visão do Brasil. Rio de Janeiro, Brasil. Fundação Instituto Brasileiro de Geografia e Estatística. p. 87-95.
Rossi LMB. 1994. Aplicações de diferentes métodos de análise para determinação de padrão espacial de espécies arbóreas da floresta tropical úmida de terra firme. Thesis Magister in Tropical Biology and Natural Resources. Manaus, Brasil. Instituto Nacional de Pesquisas da Amazônia, Fundação Universidade do Amazonas. 91 p.

Shimatani K, Y Kubota. 2004. Quantitative assessment of multispecies spatial pattern with high species diversity. Ecological Research 19(2): 149-163.

Silva JNM, JCA Lopes, LC Oliveira, SMA Silva, JOP Carvalho, DHM Costa, MS Melo, MJM Tavares. 2005. Diretrizes para instalação e medição de parcelas permanentes em florestas naturais da Amazônia Brasileira. Belém, Brasil. Embrapa Amazônia Oriental. 36 p.

Silva KE. 2010. Florística e estrutura espacial: 15 hectares de parcelas permanentes na floresta densa de terra firme na Amazônia Central. Thesis in Forestry Science. Viçosa, Brasil. Universidade Federal de Viçosa. 89 p.

Silva KE, SV Martins, CAAS Ribeiro, NT Santos, CP Azevedo, FDA Matos, IL Amaral. 2011. Floristic composition and similarity of 15 hectares in Central Amazon, Brazil. Revista de Biología Tropical 59(4): 1927-1938.

Tuomisto H, K Ruokolainen. 1994. Distribution of Pteridophyta and Melastomataceae along an edaphic gradient in an Amazonian rain forest. Journal of Vegetation Science 5(1): 25-34.

Tuomisto H. 2006. Edaphic niche differentiation among Polybotrya ferns in western Amazonia: implications for coexistence and speciation. Ecography 29(3): 273-284.

Valencia R, RB Foster, GV Richard. 2004. Tree species distribution and local habitat variation in the Amazon: large forest plot in eastern Ecuador. Journal of Ecology 92(2): 214229.

Wagner HH. 2003. Spatial covariance in plant communities: integrating ordination, geostatistics, and variance testing. Eco$\log y$ 84(4): 1045-1057.

Wiegand T, KAMoloney. 2004. Rings, circles, and null-models for point pattern analysis in ecology. Oikos 104(2): 209229.

Wiens JA. 1989. Spatial scaling in ecology. Functional Ecology 3(4): 385:97. 
